\title{
PENGEMBANGAN KEWIRAUSAHAAN DI SMA NEGERI 1 SUNGGAL KABUPATEN DELI SERDANG MELALUI KEGIATAN PELATIHAN AKUNTANSI
}

\author{
Dito Aditia Darma Nasution', Handriyani Dwilita², Vina Arnita ${ }^{3}$ \\ 1 Universitas Pembangunan Panca Budi. \\ email: ditoaditia@dosen.pancabudi.ac.id \\ ${ }^{2}$ Universitas Pembangunan Panca Budi. \\ email: handriyanidwilita@dosen.pancabudi.ac.id \\ 3Universitas Pembangunan Panca Budi. \\ email: vinaarnita@dosen.pancabudi.ac.id
}

\begin{abstract}
State Senior High School 1 Sunggal Deli Serdang Regency, which has high quality students have a high enthusiasm in entrepreneurship so that the potential to be able to bring up successful young entrepreneur. The success of coaching young people into entrepreneurs will increase regional scale economic prosperity in this case in Deli Serdang Regency even on a national scale (Indonesian). Activities carried out in this community service is in the form of accounting training activities for students of State Senior High School 1 Sunggal Deli Serdang Regency. The purpose of this activity is to develop entrepreneurship for students Senior High School 1 Sunggal Deli Serdang Regency so that it becomes a successful young entrepreneur. The results of community service activities indicate an increase in knowledge and accounting skills in entrepreneurship by Senior High School 1 Sunggal Deli Serdang Regency students.
\end{abstract}

Keywords: entrepreneurship; accounting training; successful young entrepreneurs

\begin{abstract}
ABSTRAK
Sekolah Menengah Atas Negeri 1 Sunggal Kabupaten Deli Serdang yang memiliki Siswa/siswi yang berkualitas dan mempunyai semangat tinggi dalam berwirausaha sehingga berpotensi untuk dapat memunculkan entrepreneur muda yang sukses. Keberhasilan pembinaan generasi muda menjadi entrepreneur akan meningkatkan kesejahteraan ekonomi skala daerah dalam hal ini di Kabupaten Deli Serdang bahkan skala nasional (Indonesia). Kegiatan yang dilakukan dalam pengabdian masyarakat ini adalah berupa kegiatan pelatihan akuntansi kepada Siswa/siswi Sekolah Menengah Atas Negeri 1 Sunggal Kabupaten Deli Serdang. Tujuan kegiatan ini adalah untuk mengembangkan kewirausahaan kepada Siswa/siswi Sekolah Menengah Atas Negeri 1 Sunggal Kabupaten Deli Serdang sehingga menjadi entrepreneur muda yang sukses. Hasil dari kegiatan pengabdian kepada masyarakat menunjukkan adanya peningkatan pengetahuan dan keterampilan akuntansi dalam berwirausaha oleh Siswa/siswi Sekolah Menengah Atas Negeri 1 Sunggal Kabupaten Deli Serdang.
\end{abstract}

Kata Kunci: kewirausahaan; pelatihan akuntansi; entrepreneur muda sukses 


\section{PENDAHULUAN}

Berwirausaha adalah suatu kegiatan yang dapat menumbuhkan perekonomian suatu negara. Berwirausaha dapat dilakukan oleh siapapun, termasuk seorang Siswa/siswi Sekolah Menengah Atas (SMA). Semua tergantung kepada kemauan dan dasar keilmuan sebagai pendukung untuk memulai suatu usaha. Dasar keilmuan untuk mendukung seorang bisa berwirausaha salah satunya adalah keilmuan bidang akuntansi. Keilmuan bidang akuntansi di harapkan mampu menjadi stimulus dalam membangun mainset dan memotivasi seseorang bahwa dengan analisis akuntansi yang baik, maka peluang gagalnya seseorang dalam berwirausaha dapat diminimalisasikan.

Peningkatan jumlah wirausaha baru dan pengembangan jiwa kewirauasahaan bagi Siswa/siswi SMA sejak dini sangat penting untuk dilakukan mengingat masih banyak ditemukan para wirausaha baru yang kurang mampu mempertahankan usahanya karena kurangnya keilmuan pendukung dalam berwirausaha. Selain itu berdasarkan hasil survey yang dilakukan oleh Manurung (2013) wirausaha baru memiliki resiko kegagalan dalam berwirausaha yang lebih tinggi, hal ini dikarenakan belum diperkenalkannya keilmuan pendukung wirausaha sejak dini serta banyak pelaku wirausaha baru yang belum memiliki jiwa kewirausahaan. Hasil survey tersebut juga didukung oleh Isa (2007) yang menyatakan bahwa wirausaha muda yang baru akan relatif kurang memiliki jiwa kewirausahaan dan belum tertarik mengembangkan keilmuan pendukung wirausaha, hal ini karena mereka hanya menganggap kewirausahaan sebagai pekerjaan sampingan, selain menjadi Aparatur Sipil Negara (ASN) dan pegawai swasta lainnya.

Kewirausahaan merupakan sikap dan perilaku wirausaha. Wirausaha ialah orang yang inovatif, antisipatif, inisiatif, pengambil risiko dan berorientasi laba (Fikri et al, 2015). Hal tersebut berarti dapat disimpulkan bahwa kewirausahaan harus didukung dengan sikap dan perilaku yang inovatif, antisipatif, inisiatif, pengambil risiko dan berorientasi laba. Pendapat lain terkait kewirausahaan juga dikemukakan oleh Prasetyo \& Muis (2015) yang menjelaskan kewirausahaan merupakan suatu proses melakukan sesuatu yang baru dan berbeda dengan tujuan menciptakan kesejahteraan bagi individu dan memberi nilai tambah pada masyarakat. kewirausahaan pada dasarnya di landasi atas kompetensi dan kemauan nyata seorang individu, yang berasal dari diri mereka sendiri, dalam tim, di dalam organisasi, maupun di luar organisasi yang ada, untuk menemukan dan menciptakan peluang ekonomi baru sehingga mampu menggerakkan perekonomian secara pribadi, kelompok, bahkan negara. Hal tersebut sejalan dengan Nasution (2016) yang menyatakan bahwa SDM merupakan salah satu elemen organisasi yang sangat penting, oleh karena itu harus dipastikan bahwa pengelolaan SDM dilakukan sebaik mungkin agar mampu memberikan kontribusi secara optimal dalam upaya pencapaian tujuan. 
Pengembangan kewirausahaan di SMA Negeri 1 Sunggal Kabupaten Deli Serdang merupakan kegiatan untuk menumbuhkan jiwa kewirausahaan dan memberikan pemahaman keilmuan pendukung dalam hal ini di bidang akuntansi melalui pelatihan akuntansi sehingga Siswa/siswi di SMA Negeri 1 Sunggal Kabupaten Deli Serdang sebagai calon wirausaha muda mampu melakukan analisis akuntansi yang baik untuk di aplikasikan dalam berwirausaha.

Potensi kewirausahaan di SMA Negeri 1 Sunggal Kabupaten Deli Serdang harus diakui sangat tinggi hal ini diukur dari banyaknya fasilitas yang dimiliki sekolah guna merangsang jiwa kewirausahaan kepada Siswa/siswinya. Fasilitas tersebut antara lain: business center, OSIS seksi usaha/kegiatan, koperasi sekolah, dan kerjasama bisnis dengan pihak ketiga melalui Usaha Kecil Menengah Sekolah (UKMS). Berdasarkan data laporan kegiatan SMA Negeri 1 Sunggal Kabupaten Deli Serdang tahun 2019 minat Siswa/siswi untuk terlibat dalam fasilitas kewirausahaan sekolah secara berurutan yaitu OSIS seksi usaha/kegiatan berjumlah 64 Siswa/siswi, koperasi sekolah berjumlah 31 Siswa/siswi, UKMS berjumlah 26 Siswa/siswi, dan business center berjumlah 14 Siswa/siswi.

Berikut ini disajikan diagram minat Siswa/siswi yang terlibat dalam fasilitas kewirausahaan SMA Negeri 1 Sunggal Kabupaten Deli Serdang periode tahun 2017-2019 pada gambar berikut:

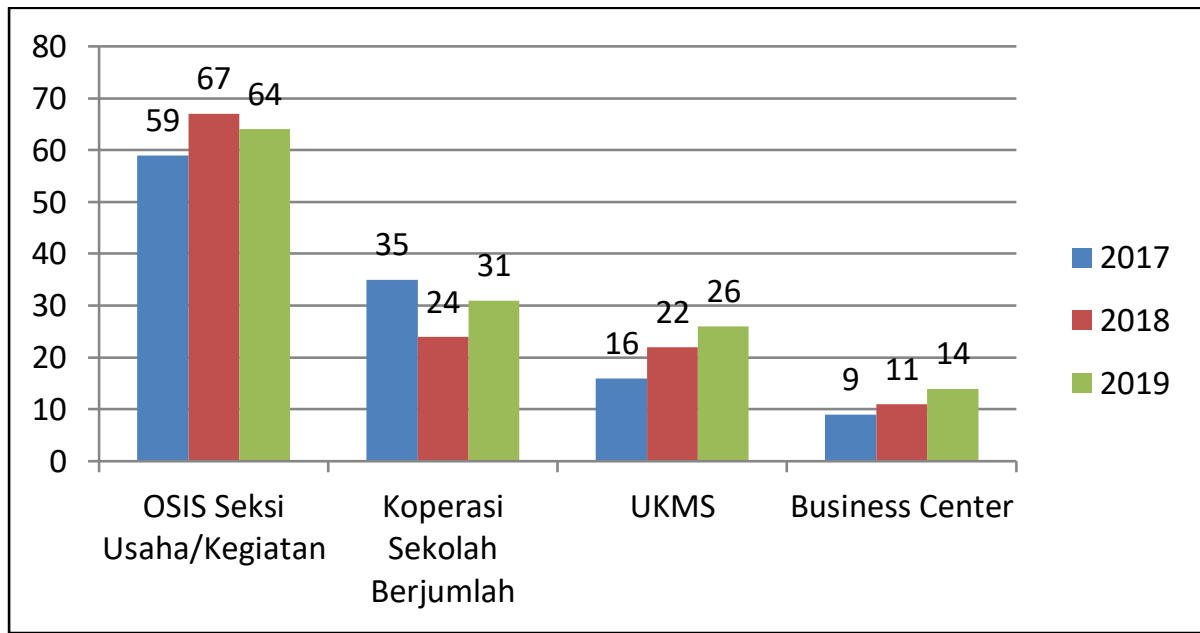

Gambar 1. Diagram Minat Siswa/siswi yang Terlibat dalam Fasilitas Kewirausahaan SMA Negeri 1 Sunggal Kabupaten Deli Serdang periode tahun 2017-2019

Berdasarkan diagram tersebut, minat Siswa/siswi yang terlibat dalam Osis Seksi Usaha/Kegiatan paling tinggi diantara fasilitas kewirausahaan yang lainnya, akan tetapi jumlah setiap tahunnya masih mengalami fluktuasi dan tidak menunjukkan peningkatan tren. Jika dilakukan penjumlahan terhadap keseluruhan Siswa/siswi yang terlibat dalam seluruh fasilitas kewirausahaan 
SMA Negeri 1 Sunggal Kabupaten Deli Serdang pada periode tahun 2019 akan diperoleh jumlah 135 Siswa/siswi akan tetapi hal tersebut masih sangat rendah jika dibandingkan dengan jumah keseluruhan Siswa/siswi SMA Negeri 1 Sunggal Kabupaten Deli Serdang yang berjumlah total 1615 Siswa/siswi, tentu hal ini dapat disimpulkan bahwa Siswa/siswi SMA Negeri 1 Sunggal Kabupaten Deli Serdang masih belum memiliki minat atau ketertarikan terhadap kewirausahaan.

SMA Negeri 1 Sunggal Kabupaten Deli Serdang yang memiliki siswa/siswi yang berkualitas dan memiliki fasilitas kewirausahaan yang baik dapat memunculkan entrepreneur muda yang sukses sehingga dapat meningkatkan kesejahteraan ekonomi skala daerah dalam hal ini di Kabupaten Deli Serdang bahkan skala nasional (Indonesia). Hanya saja untuk memaksimalkan hal tersebut diperlukan keilmuan pendukung dalam hal ini adalah keilmuan bidang akuntansi sehingga Siswa/siswi memiliki dasar keilmuan untuk mendukung kelancaran dalam berwirausaha serta untuk menambah minat Siswa/siswi dalam berwirausaha. Keilmuan bidang akuntansi di harapkan mampu menjadi stimulus dalam membangun mainset dan memotivasi Siswa/siswi bahwa dengan analisis akuntansi yang baik, maka peluang gagal dalam berwirausaha dapat diminimalisasikan. Pengabdian kepada masyarakat ini diselenggarakan dengan tujuan untuk mengembangkan kewirausahaan kepada Siswa/siswi SMA Negeri 1 Sunggal Kabupaten Deli Serdang sehingga menjadi entrepreneur muda yang sukses. Hal ini dilakukan melalui kegiatan pelatihan akuntansi kepada Siswa/siswi SMA Negeri 1 Sunggal Kabupaten Deli Serdang.

\section{METODE PELAKSANAAN}

Pengembangan kewirausahaan di SMA Negeri 1 Sunggal Kabupaten Deli Serdang melalui kegiatan pelatihan akuntansi diharapkan mampu memberikan pengetahuan dan keterampilan akuntansi dalam berwirausaha, hal tersebut karena berdasarkan hasil pre-test ditemukan bahwa pengetahuan dan keterampilan Siswa/siswi SMA Negeri 1 Sunggal Kabupaten Deli Serdang terhadap pentingnya akuntansi dalam kewirausahaan masih rendah.

Metode yang digunakan untuk mewujudkan tujuan dari pengembangan kewirausahaan di SMA Negeri 1 Sunggal Kabupaten Deli Serdang melalui kegiatan pelatihan akuntansi adalah metode pendekatan questioning lecture yaitu metode pendekatan dengan penyajian materi disertai dengan tanya jawab serta ditambah dengan pelaksanaan pre-test dan post-test untuk mengukur kemampuan Siswa/siswi sehingga dapat mengatasi permasalahan yang ada.

Prosedur kerja dilaksanakan dengan 3 (tiga) tahapan prosedur, antara lain: 1) tahap persiapan, 2) tahap pelaksanaan dan 3) tahap pelaporan yang masing-masing tahapannya dilaksanakan dengan sistematis dan terstruktur, sehingga pengembangan kewirausahaan di SMA Negeri 1 Sunggal Kabupaten Deli Serdang melalui kegiatan pelatihan akuntansi terlaksana dengan baik. Rencana kegiatan dilaksanakan berdasarkan prosedur kerja dan merupakan 
langkah-langkah solusi atas masalah mitra. Pada tahap persiapan tim pengabdian kepada masyarakat bersama dengan mitra menyusun rencana kegiatan, pendataan siswa/siswi, dan semua kebutuhan terkait dengan pelaksanaan kegiatan. Pada tahap pelaksanaan kegiatan dibagi menjadi 3 (tiga) aktivitas pelaksanaan, antara lain: 1) Penyajian materi, 2) Ice breaking, dan 3) sesi tanya jawab. Pada tahap pelaporan dokumentasi dan data hasil kegiatan disusun dalam laporan tertulis. Laporan tertulis disertai dengan hasil evaluasi pelaksanaan dan rekomendasi sesuai temuan yang didapatkan pada tahap pelaksanaan sehingga di waktu yang akan datang kegiatan pengembangan kewirausahaan melalui kegiatan pelatihan akuntansi dapat berjalan lebih baik.

Kegiatan pengembangan kewirausahaan melalui kegiatan pelatihan akuntansi dapat berjalan dengan baik karena peran dari SMA Negeri 1 Sunggal Kabupaten Deli Serdang sebagai mitra yang telah memberikan bantuan secara maksimal. Bantuan yang diberikan oleh mitra untuk mendukung kegiatan pengembangan kewirausahaan di SMA Negeri 1 Sunggal Kabupaten Deli Serdang melalui kegiatan pelatihan akuntansi yaitu SMA Negeri 1 Sunggal Kabupaten Deli Serdang bersedia bersama-sama berokoordinasi dalam menyusun rencana kegiatan. SMA Negeri 1 Sunggal Kabupaten Deli Serdang dengan cepat menyiapkan data siswa dan perlengkapan kegiatan dengan melibatkan guru dan wali kelas hal tersebut sangat penting sebagai persiapan bahan materi pada kegiatan ini serta SMA Negeri 1 Sunggal Kabupaten Deli Serdang juga bersedia menyiapkan fasilitas, tempat, sarana dan prasarana penunjang kegiatan sehingga kegiatan pengembangan kewirausahaan di SMA Negeri 1 Sunggal Kabupaten Deli Serdang melalui kegiatan pelatihan akuntansi dapat berjalan dengan sangat baik.

\section{HASIL DAN PEMBAHASAN}

Pelaksanaan kegiatan pengembangan kewirausahaan di SMA Negeri 1 Sunggal Kabupaten Deli Serdang melalui kegiatan pelatihan akuntansi menuai respons positif dari Siswa/siswi SMA Negeri 1 Sunggal Kabupaten Deli Serdang. Respons Siswa/siswi sebagai peserta pelatihan terlihat selama kegiatan berlangsung dengan diskusi yang menyangkut kesan, saran, kritik dan usulan peserta pelatihan terhadap kegiatan pengembangan kewirausahaan di SMA Negeri 1 Sunggal Kabupaten Deli Serdang melalui kegiatan pelatihan akuntansi ini.

Meningkatnya pemahaman akuntansi dalam kewirausahaan Siswa/siswi SMA Negeri 1 Sunggal Kabupaten Deli Serdang setelah mendapat pelatihan dapat diukur dari hasil observasi melalui tugas-tugas yang diberikan melalui post-test. Peserta kegiatan setelah diberikan pelatihan telah mampu membuat konsep dasar akuntansi dalam kewirausahaan yang mereka rancang dan susun sendiri dengan menggunakan pola fikir masing-masing siswa. 
Peserta pengabdian kepada masyarakat juga telah dapat membuka pola fikir yang kreatif dan inovatif untuk mendukung kesuksesan dalam kewirausahaan.

Peserta pelatihan pada kegiatan pengembangan kewirausahaan di SMA Negeri 1 Sunggal Kabupaten Deli Serdang melalui kegiatan pelatihan akuntansi selain diajarkan konsep dasar akuntansi dalam kewirausahaan dan pengembangan pola fikir yang kreatif dan inovatif juga diajarkan tentang dasar-dasar penyusunan laporan keuangan perusahaan sehingga memudahkan peserta dalam pengelolaan keuangan di dalam berwirausaha. Adapun yang diajarkan dalam dasar-dasar penyusunan laporan keuangan perusahaan tersebut yaitu pengenalan laporan keuangan mulai dari pengertian laporan keuangan, tujuan laporan keuangan, unsur-unsur laporan keuangan sampai kepada akun-akun yang tersedia pada laporan keuangan. Hal tersebut disajikan untuk mendukung kesuksesan para Siswa/siswi SMA Negeri 1 Sunggal Kabupaten Deli Serdang dalam berwirausaha. Penyampaian materi tersebut dapat dilihat pada gambar berikut:

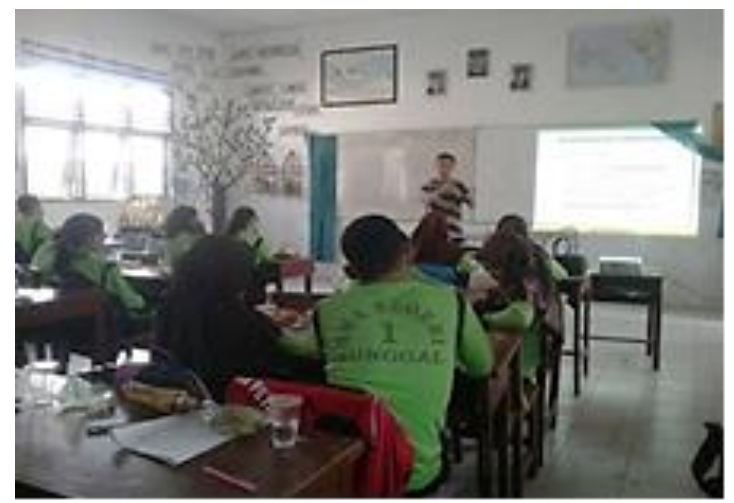

Gambar 2. Penyampaian Materi kepada Peserta Kegiatan

Peserta kegiatan pengembangan kewirausahaan di SMA Negeri 1 Sunggal Kabupaten Deli Serdang melalui kegiatan pelatihan akuntansi juga sangat aktif dalam menerima materi pelatihan yang disajikan hal ini terlihat dari antusiasme peserta dalam mengajukan pertanyaan-pertanyaan kepada narasumber sehingga mampu menaikkan semangat narasumber dalam menyampaikan materi. Selama pelaksanaan kegiatan mulai dari tahap persiapan hingga pelaksanaan dapat di sampaikan temuan-temuan yaitu pada hari pertama saat tim kegiatan pengembangan kewirausahaan di SMA Negeri 1 Sunggal Kabupaten Deli Serdang datang mengajukan ijin untuk menyelenggarakan kegiatan pelatihan akuntansi, antusiasme Kepala SMA Negeri 1 Sunggal Kabupaten Deli Serdang sangat tinggi dan menunjukkan semangat yang membara, hal tersebut dikarenakan kegiatan ini dapat membantu siswa/siswi SMA Negeri 1 Sunggal Kabupaten Deli Serdang sukses dalam berwirausaha di masa yang akan datang. Semangat dan antusias dari Kepala SMA Negeri 1 Sunggal Kabupaten Deli Serdang juga langsung terlihat 
ketika beliau langsung mengundang rapat tahap persiapan bersama tim kegiatan untuk menyusun rencana kegiatan. Kepala SMA Negeri 1 Sunggal Kabupaten Deli Serdang juga mempunyai harapan yang sangat tinggi agar kegiatan pengembangan kewirausahaan di SMA Negeri 1 Sunggal Kabupaten Deli Serdang melalui kegiatan pelatihan akuntansi ini dapat dilaksanakan secara berkala untuk menumbuhkan jiwa entrepreneur para Siswa/siswi SMA Negeri 1 Sunggal Kabupaten Deli Serdang.

Pada rapat tahap persiapan tim menyusun materi sesuai dengan level peserta pelatihan yang masih duduk di bangku SMA, agar peserta pelatihan lebih mudah memahami dan mempratekkannya tanpa memberatkannya dalam proses pemahaman. Materi kegiatan yang digunakan memberikan penyegaran dan penambahan wawasan atas pentingnya akuntansi dalam kewirausahaan. Pada saat pelaksanaan kegiatan, situasi dan kondisi kegiatan sangatlah kondusif dan memberikan kenyamanan bagi peserta pelatihan karena pelaksanaan pelatihan dilaksanakan di ruang kelas sekolah sehingga peseta merasa nyaman dalam melaksanakan pelatihannya. Dalam pelaksanaan kegiatan terlihat pemahaman Siswa/siswi SMA Negeri 1 Sunggal Kabupaten Deli Serdang terkait pentingnya akuntansi dalam kewirausahaan masih rendah, kebanyakan dari siswa/siswi peserta pengabdian tidak paham tentang konsep akuntansi dan pengaplikasiannya dalam membangun suatu usaha hal tersebut diukur dari hasil pre-test yang dilaksanakan oleh tim sebelum masuk ke dalam materi inti, sehingga dengan diadakannya kegiatan pengembangan kewirausahaan di SMA Negeri 1 Sunggal Kabupaten Deli Serdang melalui kegiatan pelatihan akuntansi diharapkan mampu meningkatkan pemahaman siswa/siswi SMA Negeri 1 Sunggal Kabupaten Deli Serdang terhadap pentingnya akuntansi dalam kewirausahaan. Antusias Siswa/siswi SMA Negeri 1 Sunggal Kabupaten Deli Serdang juga terliat saat pelaksanaan kegiatan antara lain banyaknya pertanyaan-pertanyaan yang muncul saat fase diskusi sehingga membuat suasa menjadi lebih hidup dan membuat tim menjadi lebih bersemangat dalam melaksanakan kegiatan ini. Antusias Siswa/siswi SMA Negeri 1 Sunggal Kabupaten Deli Serdang dalam bertanya dapat dilihat pada gambar berikut:

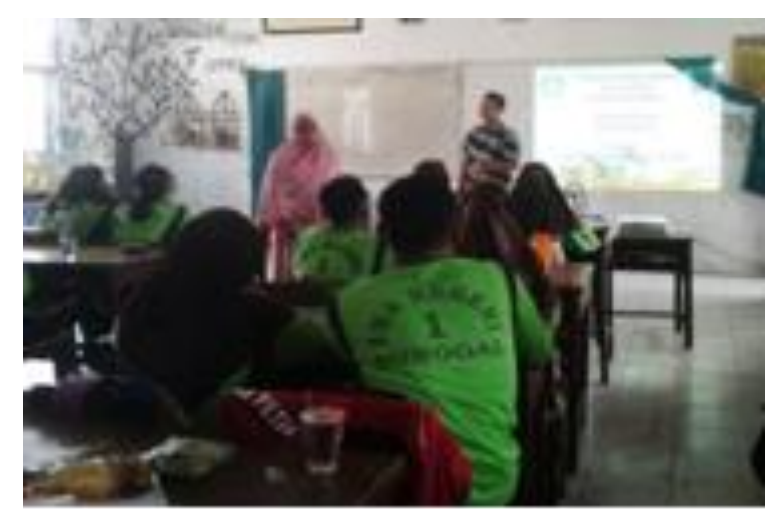

Gambar 3. Peserta Antuas dalam Bertanya 
Pada Akhir pelaksanaan kegiatan, Siswa/siswi SMA Negeri 1 Sunggal Kabupaten Deli Serdang telah memiliki kemampuan dan pemahaman konsep akuntansi dalam membangun suatu usaha. Hal tersebut diukur dari hasil posttest yang menunjukkan peningkatan kemampuan akuntansi dalam berwirausaha Siswa/siswi SMA Negeri 1 Sunggal Kabupaten Deli Serdang sehingga dapat disimpulkan kegiatan ini berjalan sesuai dengan tujuan diinginkan tim kegiatan pengembangan kewirausahaan di SMA Negeri 1 Sunggal Kabupaten Deli Serdang melalui kegiatan pelatihan akuntansi.

Setelah selesainya kegiatan pengembangan kewirausahaan di SMA Negeri 1 Sunggal Kabupaten Deli Serdang melalui kegiatan pelatihan akuntansi, tim melakukan foto bersama dengan guru/wali kelas dan pegawai SMA Negeri 1 Sunggal Kabupaten Deli Serdang yang telah memberikan kesempatan kepada tim untuk memberikan pemahaman pentingnya akuntansi dalam kewirausahaan kepada Siswa/siswi SMA Negeri 1 Sunggal Kabupaten Deli Serdang. Foto bersama dengan guru/wali kelas dan pegawai SMA Negeri 1 Sunggal Kabupaten Deli Serdang dapat dilihat pada gambar berikut:

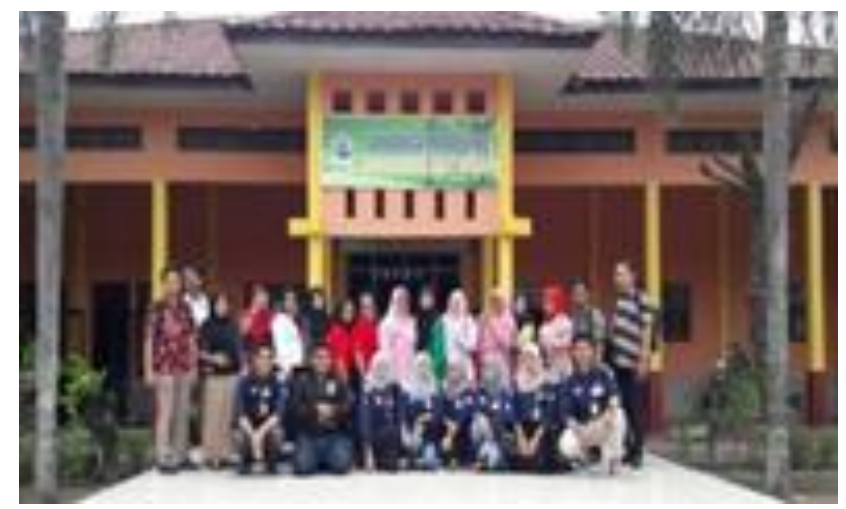

Gambar 4. Foto Bersama dengan Guru/Wali Kelas dan Pegawai

Seusai acara kami tim kegiatan pengembangan kewirausahaan di SMA Negeri 1 Sunggal Kabupaten Deli Serdang melalui kegiatan pelatihan akuntansi melaksanakan rapat rumusan akhir bersama Kepala SMA Negeri 1 Sunggal Kabupaten Deli Serdang untuk mengevaluasi kegiatan yang telah dilakukan sekaligus berpamitan dan berterima kasih atas kerjasama serta kesempatan yang diberikan. Kepala SMA Negeri 1 Sunggal Kabupaten Deli Serdang pun memberikan apresiasi kepada tim dan mengharapkan agar kegiatan ini dapat dilaksanakan secara berkala di lain kesempatan agar para Siswa/siswi SMA Negeri 1 Sunggal Kabupaten Deli Serdang memiliki jiwa dan kemampuan wirausaha yang baik yang suatu saat nanti dapat menjadi wirausaha sukses yang mampu meningkatkan kesejahteraan ekonomi baik pada skala daerah dalam hal ini di Kabupaten Deli Serdang maupun skala nasional (Indonesia). 


\section{KESIMPULAN}

Berdasarkan hasil pengukuran pre-test yang dilakukan sebelum pelaksanaan pelatihan ditemukan masih rendahnya pemahaman akuntansi dalam berwirausaha Siswa/siswi SMA Negeri 1 Sunggal Kabupaten Deli Serdang. Setelah pelaksanaan kegiatan pengembangan kewirausahaan di SMA Negeri 1 Sunggal Kabupaten Deli Serdang melalui kegiatan pelatihan akuntansi ditemukan peningkatan kemampuan akuntansi dalam beriwausaha pada Siswa/siswi SMA Negeri 1 Sunggal Kabupaten Deli Serdang. Hal ini diukur dari hasil post-test yang menunjukkan peserta telah memiliki konsep dasar akuntansi dalam kewirausahaan dan pengembangan pola fikir yang kreatif dan inovatif sehingga dapat menciptakan suatu usaha yang sukses di kemudian hari. Selain itu Siswa/siswi SMA Negeri 1 Sunggal Kabupaten Deli Serdang juga telah memahami dasar-dasar penyusunan laporan keuangan yang dapat memudahkan Siswa/siswi SMA Negeri 1 Sunggal Kabupaten Deli Serdang dalam pengelolaan keuangan di dalam berwirausaha.

Selain dari hasil yang diatas dengan diadakannya kegiatan pengembangan kewirausahaan di SMA Negeri 1 Sunggal Kabupaten Deli Serdang melalui kegiatan pelatihan akuntansi ini secara tidak langsung dapat memotivasi guru bahkan orang tua Siswa/siswi SMA Negeri 1 Sunggal Kabupaten Deli Serdang untuk lebih mendukung para Siswa/siswi menjadi wirausaha yang sukses di kemudian hari berbekal pengetahuan dan pemahaman akuntansi dalam kewirausahaan yang telah dimiliki para Siswa/siswi SMA Negeri 1 Sunggal Kabupaten Deli Serdang.

\section{DAFTAR RUJUKAN}

Fikri, A., Inapty, B. A., \& Martiningsih, R. S. P. (2015). Pengaruh Penerapan Standar Akuntansi Pemerintahan, Kompetensi Aparatur dan Peran Audit Internal terhadap Kualitas Informasi Laporan Keuangan dengan Sistem Pengendalian Intern sebagai Variabel Moderating (Studi Empiris Pada SKPD-SKPD di Pemprov. NTB). Simposium Nasional Akuntansi $X V I I I$. Medan.

Isa, M. (2007). Pengukuran Efisiensi Teknis Usaha Mebel dengan Data Envelopment Analysis (DEA). Benefit: Jurnal Manajemen Dan Bisnis, 11(1).

Manurung, H. (2013). Peluang Kewirausahaan Sekolah melalui Kreativitas dan Inovasi. Journal of Business and Entrepreneurship, 1(1), 1-28.

Nasution, D. A. D. (2016). Analisis Faktor-faktor yang Mempengaruhi Implementasi SAP Berbasis Akrual dengan Komitmen SKPD sebagai Variabel Moderating pada Pemerintah Provinsi Sumatera Utara (Tesis). Universitas Sumatera Utara. Medan.

Prasetyo, A. G., \& Muis, A. (2015). Village Financial Management After Implementation of Law No. 6/2014: Potential Problems and Solutions. Jurnal Desentralisasi, 13(1). 
Indrie Ambarsari, S., \& Choliq, A., (2009). Rekomendasi dalam penetapan standar mutu tepung ubi jalar. Ungaran: Balai Pengkajian Teknologi Pertanian (BPTP).

Perdana, R. Y., (2006). Pembuatan Mie Kering Dari Tepung Komposit (Terigu Dan Serbuk Ubi Kayu) yang Difortifikasi Tepung Kacang Tunggak. 